\title{
Fast-food intake and perceived and objective measures of the local fast-food environment in adolescents
}

\author{
Chalida Svastisalee ${ }^{1,2, *}$, Trine Pagh Pedersen ${ }^{2}$, Jasper Schipperijn ${ }^{3}$, \\ Sanne Ellegaard Jørgensen ${ }^{2}$, Biørn E Holstein ${ }^{2}$ and Rikke Krølner ${ }^{2}$ \\ 'Global Nutrition and Health, Metropolitan University College, Pustervig 8, 1126 Copenhagen K, Denmark: \\ ${ }^{2}$ National Institute of Public Health, University of Southern Denmark, Copenhagen, Denmark: ${ }^{3}$ Institute of Sports \\ Science and Biomechanics, University of Southern Denmark, Odense, Denmark
}

Submitted 23 October 2014: Final revision received 15 March 2015: Accepted 20 March 2015: First published online 6 May 2015

\begin{abstract}
Objective: We examined associations between fast-food intake and perceived and objective fast-food outlet exposure.

Design: Information from the Health Behaviours in School-aged Children Study was linked to fast-food outlets in seventy-five school neighbourhoods. We used multivariate multilevel logistic regression analyses to examine associations between at least weekly fast-food intake and perceived and objective fast-food outlet measures.

Subjects: Data represent 4642 adolescents (aged 11-15 years) in Denmark.

Results: Boys reporting two or more fast-food outlets had $34 \%$ higher odds consuming fast food at least weekly. We detected higher odds of at least weekly fast-food intake among 15-year-old 9th graders $\left(\mathrm{OR}_{\text {all }}=1 \cdot 74 ; 95 \%\right.$ CI 1.40, 2.18; $\mathrm{OR}_{\text {boys }}=2 \cdot 20 ; 95 \%$ CI 1.66, 2.91; $\mathrm{OR}_{\text {girls }}=1 \cdot 41 ; 95 \%$ CI 1.03, 1.92), Danish speakers $\left(\mathrm{OR}_{\mathrm{all}}=2 \cdot 32 ; 95 \%\right.$ CI 1.68, 3.19; $\mathrm{OR}_{\mathrm{boys}}=2 \cdot 58 ; 95 \%$ CI 1.69, 3.93; $\mathrm{OR}_{\text {girls }}=2 \cdot 37$; $95 \%$ CI $1 \cdot 46,3 \cdot 84)$ and those travelling $15 \mathrm{~min}$ or less to school $\left(\mathrm{OR}_{\text {all }}=1 \cdot 21 ; 95 \%\right.$ CI 1.00, 1.46; OR girls $_{1}=1.44 ; 95 \%$ CI 1.08, 1.93) compared with 11-year-old 5th graders, non-Danish speakers and those with longer travel times. Boys from middle- $(\mathrm{OR}=1.28 ; 95 \%$ CI $1.00,1.65)$ and girls from low-income families $(\mathrm{OR}=1.46 ; 95 \%$ CI 1.05, 2.04) had higher odds of at least weekly fast-food intake compared with those from high-income backgrounds. Girls attending schools with canteens $(\mathrm{OR}=1 \cdot 47 ; 95 \%$ CI $1 \cdot 00,2 \cdot 15)$ had higher odds of at least weekly fastfood intake than girls at schools without canteens.

Conclusions: The present study demonstrates that perceived food outlets may impact fast-food intake in boys while proximity impacts intake in girls. Public health planning could target food environments that emphasize a better understanding of how adolescents use local resources.
\end{abstract}

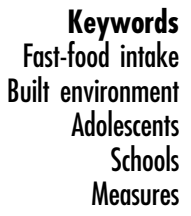

Fast food, which is characterized not only by nutritional content, large portion sizes and energy density ${ }^{(1)}$, but also by short preparation time and the types of places in which it is sold $^{(2)}$, is associated with weight gain and obesity in children and adolescents ${ }^{(3-5)}$ and an increasing risk of developing chronic disease later in life $\mathrm{e}^{(6)}$. Approximately one-third of 12-16-year-old adolescents in the USA eat fast food regularly ${ }^{(7)}$, accounting for $30-50 \%$ of total energy intake $^{(8,9)}$, and displacing other foods necessary for growth and overall health ${ }^{(10)}$. The increase in the number of fast-food oulets in the USA ${ }^{(11)}$ may be one factor that could explain increased trends in fast-food consumption among US 12-16-year-olds. While similar trends in fast-food consumption may not be as highly published elsewhere, growing evidence indicates that fast food plays an influential role in adolescent diets in other countries ${ }^{(12,13)}$. Hence, the present research focused on examining to what extent access to fast-food outlets, known providers of energy-dense foods, is associated with fast-food intake in adolescents in school neighbourhoods in Denmark.

Physical access to fast-food outlets may provide one explanation for increased fast-food intake. Studies conducted in North America using geocoded information show clustering of fast-food restaurants and convenience stores within 400- to $800-\mathrm{m}$ walking distances to schools ${ }^{(14-22)}$, often within lower-income neighbourhoods ${ }^{(15-17,20-22)}$. Outside North America, one study from New Zealand corroborated similar spatial patterning ${ }^{(23)}$, 
while a longitudinal study in the UK demonstrated an increase in the patterning of convenience stores around schools within $800 \mathrm{~m}^{(24)}$. These findings are troubling given the relatively easy access young people may have to energy-dense foods as they pass these outlets during their travel to and from school, priming adolescents into making unhealthy food choices ${ }^{(25)}$.

Whether proximal exposure of fast-food outlets is associated with fast-food intake among adolescents is still largely understudied, despite growing research interest ${ }^{(26)}$. Current findings are mixed among studies using objective measures of food-outlet exposure. A recent US study in rural New Hampshire and Vermont demonstrated that adolescents were more than $30 \%$ more likely to consume fast food in towns with five or more fast-food outlets ${ }^{(27)}$. Another US study ${ }^{(18)}$ investigating pooled information from over 500000 students in California reported decreased fruit and vegetable consumption and increased soda intake when fast-food outlets were within 0.5 mile $(800 \mathrm{~m})$ from the school. In a study conducted in Ontario, Canada, He and colleagues ${ }^{(26)}$ showed adolescents living in close proximity to convenience stores to have lower indices of healthy eating, while those attending schools in close proximity to fast-food outlets or convenience stores exhibited lower healthy eating indices. By contrast, a study conducted in Rotterdam, the Netherlands ${ }^{(28)}$ found little association between soft drink and snack consumption and food outlets within $500 \mathrm{~m}$ of the school in approximately 1300 adolescents. Likewise, a US study ${ }^{(29)}$ in Minneapolis/St. Paul found little association between exposure to any food outlets in surrounding school areas (800, 1600 and $3000 \mathrm{~m}$ from the school) and dietary intake of 349 adolescents. Despite US findings showing food outlets are clustered around schools ${ }^{(14-22)}$, existing evidence between local fast-food outlet exposure and eating behaviour among adolescents outside US contexts is limited $^{(24)}$, prompting further investigation.

Nevertheless, the use of objective measures has resulted in valuable contributions to our understanding of how built environments contribute to dietary behaviours. However, Caspi and colleagues ${ }^{(30)}$ argue for the need to incorporate information other than objective built environment measures, as their sole reliance may be prone to classification bias $^{(2)}$ and discrepancies in location or trading hours $^{(31,32)}$, which ultimately distort the relationship between the built environment and dietary behaviour.

Incorporating perceived information about the built environment in addition to objective measures may bring an added dimension to our understanding of how people use their surrounding neighbourhoods. There are few studies that examine both perceived and objective measures of the food environment and dietary intake. Among studies of adults, it has been suggested that these measures, while correlated, are not the same ${ }^{(33)}$ and cannot serve as proxies for each other ${ }^{(34)}$. Perceived information of the food environment could, for instance, represent different constructs of adult dietary behaviour, such as food quality $^{(33,35)}$ or food preference ${ }^{(30)}$, that cannot be captured by objective data. Although objective information was not used, a study by Hearst and colleagues ${ }^{(36)}$ demonstrated that perceived proximity of fast-food outlets was associated with consumption of snack foods, soft drinks and purchasing behaviour among adolescents. While both perceived and objective measures of the food environment could provide unique insight into adolescent dietary behaviours, there are presently no published studies that concurrently examine objective and perceived exposure to fast-food outlets and relationships with dietary behaviours in an adolescent population. The aim of the present study was to examine the association between fast-food intake in adolescents and perceived and objective exposure to fastfood outlets in the local school area. We hypothesize that perceived and objective proximity of fast-food outlets are the exposures and fast-food intake is the outcome. Study results are valuable for improving health interventions and urban planning that enable healthy lifestyles.

\section{Methods}

\section{Design and study population}

We used data from the Danish contribution to the international Health Behaviour in School-aged Children (HBSC) Study, a cross-sectional examination of health and health behaviours in 11-, 13- and 15-year-old children in nationally representative samples of schools ${ }^{(37)}$. In 2010, 137 randomly selected schools were invited to partake in the Danish HBSC Study, whereby seventy-three of these schools consented to participate. Of 5704 students enrolled in 5 th, 7 th and 9 th grades $(11,13$ and 15 years of age, respectively), a total of 4922 (86.3\%) answered the internationally standardized HBSC questionnaire ${ }^{(38)}$ during one class period.

All surveys were conducted anonymously and identifiable only by participant number, making comparisons between participants and non-participants unfeasible. School principals also answered a short questionnaire about school facilities and rules and policies about leaving school campus (response rate $=84 \%, n$ 63).

\section{Outcome measure}

Students were asked to report on frequency of fast-food consumption expressed in the question, 'How many times a week do you usually eat fast food?' Students were prompted with examples of food items such as burgers, sausages, pizza and shawarma (response key: $1=$ never, $2=<$ once/ week, $3=$ once/week, $4=2-4 \mathrm{~d} /$ week, $5=5-6 \mathrm{~d} /$ week, $6=$ once/d, $7=>$ once/d). Questions and key response categories were tested prior to survey administration. Based on the response distribution, we dichotomized the outcome measure to reflect fast-food consumption of at least weekly ( $\geq 1$ time/week) $v$. less than weekly ( $<1$ time/week). A total 
of sixty-nine (1.4\%) students were missing information on the outcome measure and were subsequently excluded from analysis.

\section{Exposure variables}

Perceived measure of fast-food outlet exposure

Students were also asked to report whether they encountered food outlets selling fast food within a 5-min walking trip from school (response key: $0=$ none, $1=$ one, $2=$ two or more, $4=$ don't know). A total of fifty-two $(1 \cdot 1 \%)$ students were missing information about fast-food outlet exposure and were also excluded from analysis, while $502(10 \cdot 2 \%)$ of the students answered that they did not know whether a fast-food outlet was near the school.

\section{Objective measure of fast-food outlet exposure}

Information from the 2010 Danish HBSC Study shows that over $75 \%$ of the study population travels $15 \mathrm{~min}$ or less to school, while $64 \%$ of the study population travels either on foot or by bicycle, indicating that school catchment areas are also reflective of their students' home neighbourhood environments. During the administration of the 2010 study, we obtained addresses for all food outlets from the Smiley Registry, a quarterly database maintained by the Danish Veterinary and Food Administration, which is responsible for all food safety inspection reports (www.findsmiley.dk). Using school zipcodes as the initial sourcing area, we retrieved 3367 addresses for all food outlets (e.g. supermarkets, convenience stores both within petrol stations and free standing, bakeries, fast-food outlets and restaurants) and geocoded them using ArcGIS 9.1 (ESRI, Redlands, CA, USA). In order to examine the overall quality of address listings, we compared the health inspection database with two Internet-based search engines for address information: Krak.dk ( $n$ 3329; www.krak.dk) and Google Maps ( $n$ 3328; www.googlemaps.dk). Additionally, eight school areas in rural and urban areas were selected and food outlets were validated by street inventory methods as described in previous studies ${ }^{(32,39)}$, representing a 6-month time lag between the time the data were initially collected to the finalization of data validation. Positive predictive value, as categorized by Pacquet and colleagues ${ }^{(40)}$, showed good overlap between the Smiley registry and Krak.dk (81\%) and moderate overlap with Google Maps (58\%). Positive predictive values for fast-food outlets alone were $83 \%$ and $65 \%$, respectively.

Using ArcGIS 9.2, we created $500 \mathrm{~m}$ radial buffers surrounding each of the study schools, using the schools as buffer centroids. Based on these buffer maps, we enumerated the number of fast-food outlets within a $500 \mathrm{~m}$ radius of each school and used this information for further analysis in statistical modelling. A total of seventy-five fastfood outlets were identified in the present study. Previous distance measures used in food built environment studies examined ranges between 400 and $800 \mathrm{~m}$ from the school $^{(14,15,18,28,41,42)}$. We used $500 \mathrm{~m}$ to reflect studentreported measure of 5-min walking distance from the school, according to the average walking speed for children at $83 \mathrm{~m} / \mathrm{min}^{(43)}$. Exposure to fast-food outlets was then expressed as a total count surrounding each school and categorized $(0=$ zero outlets, $1=$ one outlet, $2=$ two or more outlets) to match the answer categories used by the students about their perceived exposure to fast-food outlets.

\section{Covariates}

We considered sociodemographic variables associated with differences in fast-food intake, as fast-food consumption tends to be higher in boys ${ }^{(7,44,45)}$, older adolescents ${ }^{(46)}$ and low social class ${ }^{(46)}$. Family social class was determined by student report of job title and place of work of the mother and father. Each occupation was coded by the research group into one of five social class variables ( $\mathrm{I}=$ high to $\mathrm{V}=$ low) using classification standards previously described elsewhere ${ }^{(47)}$. We recoded social class into four levels, high (I-II), middle (III-IV), low (V and economically inactive) and unclassified, excluding students with missing family social class information ( $n$ 88). Lastly, the student's home language other than Danish may be associated with immigration status, potentially representing groups with differing food choices.

We also considered behavioural correlates reflecting the school lunch context, such as the presence of a school canteen ${ }^{(48-50)}$, which may be associated with healthy eating $^{(51,52)}$ and minimize the likelihood of consuming lunch elsewhere. In Denmark, provision of school cafeterias is not considered the norm, necessitating that most children attending school bring lunch from home ${ }^{(53,54)}$. Of late, there has been interest in ensuring the nutritional quality of packed school lunch, due to the introduction of school health initiatives and food policies ${ }^{(55)}$. However, such policies are enforced and implemented on a schoolby-school basis.

School travel time and mode may be related to perception of fast-food outlet exposure, as students with short travel times to or from school may be more likely to either walk or cycle to school, thereby increasing exposure to shops within the local area ${ }^{(36)}$. Based on distributions of student responses, we compared students with travel times of $15 \mathrm{~min}$ or less $v$. more than $15 \mathrm{~min}$ to or from school. We examined differences in reporting between those who walked to school $v$. those with wheeled transport (cycling and motorized combined), as students walking to or from school would most likely be exposed to food-buying options due to increased contact time in the local area ${ }^{(56)}$.

School policies, whether students were allowed to leave school, and the presence of a school cafeteria may limit or restrict access to fast food ${ }^{(57)}$. Based on data from the school principal, we examined differences between 
schools allowing students to leave campus during school hours $v$. schools that did not. We also examined presence $v$. absence of a school cafeteria.

\section{Statistical analyses}

Analysis was based on seventy-five school neighbourhoods and 4642 students with complete data on all covariates and outcome measures. Statistical analyses were conducted in the SAS statistical software package version 9.2. We determined fast-food intake, and tested for differences between boys and girls, between grades and between family social classes using $\chi^{2}$ statistics. Spearman correlation analyses were performed to ensure all neighbourhood-level variables were independently distinct from each other (range from -0.002 to 0.380 ). As we initially detected differences in fast-food intake between boys and girls and in order to separate sex-related differences, we conducted combined and sex-stratified analyses, examining the likelihood of eating fast food at least weekly among students. We used logistic multilevel regression analysis (Proc Glimmix) to control for the cluster design of the study (random school and class effects).

\section{Results}

Over $30 \%$ of the students reported at least weekly intake of fast food (Table 1). Over $60 \%$ reported one or more fast-food outlets surrounding the school, while $45 \%$ of the students ( $n$ 2216) attended twenty-four schools with at least one fast-food outlet within $500 \mathrm{~m}$ distance, as determined by the objective measure.

In Table 2, we show $\chi^{2}$ analysis for all students and separately for boys and girls. Levels of at least weekly fast-food intake were statistically different among students and boys and girls, with the proportion of intake levels generally being higher with greater levels of perceived and objectively measured fast-food outlets. At least weekly fast-food consumption increased proportionally with age, while a high to low gradient in intake was detected for all students and girls. More than $31 \%$ of students with at least weekly intake of fast food travelled less than $15 \mathrm{~min}$ to school on a daily basis. More than $28 \%$ of students with at weekly fast-food intake attended schools with a school leaving policy, while $35 \%$ of these students attended schools with a canteen on the premises.

In Table 3, we show multivariate multilevel logistic regression models for associations between correlates and at weekly fast food intake for all students and stratified by sex. Objective exposure to fast-food outlets was not associated with at least weekly fast-food intake in any of the models, but boys had $34 \%$ higher odds of fast-food consumption on an at least weekly basis if they perceived two or more fastfood outlets in the school neighbourhood compared with those reporting no outlets. Boys also had $78 \%$ higher odds of eating fast food at least weekly than girls.
Table 1 Descriptive statistics for measures and correlates; adolescents ( $n$ 4642) aged 11-15-years, Danish HBSC study, 2010

\begin{tabular}{|c|c|c|}
\hline & $n$ & $\%$ \\
\hline \multicolumn{3}{|l|}{ Measure description } \\
\hline \multicolumn{3}{|l|}{ Frequency of fast food } \\
\hline Less than once weekly & 3353 & $68 \cdot 12$ \\
\hline Once weekly or more & 1500 & 30.48 \\
\hline Missing (excluded) & 69 & 1.40 \\
\hline \multicolumn{3}{|l|}{ Student-perceived fast-food outlet measure } \\
\hline None (ref.) & 1190 & $24 \cdot 18$ \\
\hline One outlet & 1217 & 24.73 \\
\hline Two or more outlets & 1961 & $39 \cdot 84$ \\
\hline Don't know, recoded to none (excluded) & 502 & $10 \cdot 19$ \\
\hline Missing (excluded) & 52 & 1.06 \\
\hline \multicolumn{3}{|l|}{ Objective fast-food outlet measure } \\
\hline Zero outlets; 51 schools (ref.) & 2706 & 54.98 \\
\hline One outlet & 913 & 18.55 \\
\hline Two or more outlets & 1303 & $26 \cdot 47$ \\
\hline \multicolumn{3}{|l|}{ Correlates of fast-food intake } \\
\hline \multicolumn{3}{|l|}{ Sex } \\
\hline Girls (ref.) & 2458 & $49 \cdot 94$ \\
\hline Boys & 2464 & 50.06 \\
\hline \multicolumn{3}{|l|}{ Grade } \\
\hline 5th (ref.) & 1839 & $37 \cdot 36$ \\
\hline 7th & 1652 & 33.56 \\
\hline 9th & 1431 & 29.08 \\
\hline \multicolumn{3}{|l|}{ Family social class } \\
\hline High (ref.) & 1612 & $32 \cdot 75$ \\
\hline Middle & 1760 & $35 \cdot 76$ \\
\hline Low & 799 & $16 \cdot 23$ \\
\hline Unclassified & 663 & 13.47 \\
\hline Missing (excluded) & 88 & 1.79 \\
\hline \multicolumn{3}{|l|}{ Language spoken at home } \\
\hline Danish (ref.) & 4470 & $90 \cdot 82$ \\
\hline Other & 295 & 5.99 \\
\hline Missing (excluded) & 157 & 3.19 \\
\hline \multicolumn{3}{|l|}{ School travel time } \\
\hline $15 \mathrm{~min}$ or less (ref.) & 3822 & $77 \cdot 65$ \\
\hline More than $15 \mathrm{~min}$ & 1062 & 21.58 \\
\hline Missing (excluded) & 38 & 0.77 \\
\hline \multicolumn{3}{|l|}{ School leader-reported items } \\
\hline \multicolumn{3}{|l|}{ Students allowed to leave school } \\
\hline Allowed for some (ref.) & 30 & $40 \cdot 00$ \\
\hline Not allowed at all & 39 & $52 \cdot 00$ \\
\hline Missing (excluded) & 6 & 8.00 \\
\hline \multicolumn{3}{|l|}{ Presence of school canteen } \\
\hline No (ref.) & 55 & $73 \cdot 33$ \\
\hline Yes & 8 & $10 \cdot 67$ \\
\hline Missing (excluded) & 12 & $16 \cdot 00$ \\
\hline
\end{tabular}

HBSC, Health Behaviour in School-aged Children; ref., referent category.

Significant correlates of at least weekly fast food intake were generally similar for both boys and combined student models. For instance, 9th grade students and 9th grade boys had 1.74 and 2.20 higher odds, respectively, to consume fast food on an at least weekly basis compared with their 5 th grade referents. Likewise, students and boys speaking Danish at home had 2.32 and 2.58 higher odds of at least weekly fast-food intake, respectively, compared with students and boys speaking another language. Boys from middle social class backgrounds had 1.28 higher odds of at least weekly fast-food intake than their high social class referents. Lastly, students with travel times $15 \mathrm{~min}$ or less had $21 \%$ higher odds of at least weekly fast-food consumption than those with greater travel times to school. 
Table 2 Proportion of students with at least weekly intake of fast food by sociodemographic characteristics and neighbourhood variables; adolescents ( $n$ 4642) aged 11-15-years, Danish HBSC study, 2010

\begin{tabular}{|c|c|c|c|c|c|c|}
\hline & \multicolumn{2}{|c|}{ All students } & \multicolumn{2}{|r|}{ Boys } & \multicolumn{2}{|r|}{ Girls } \\
\hline & \multicolumn{2}{|c|}{$\begin{array}{l}\text { At least weekly fast-food } \\
\text { intake }=1409 / 4642\end{array}$} & \multicolumn{2}{|c|}{$\begin{array}{l}\text { At least weekly fast-food } \\
\text { intake }=840 / 2301\end{array}$} & \multicolumn{2}{|c|}{$\begin{array}{l}\text { At least weekly fast-food } \\
\text { intake }=569 / 2341\end{array}$} \\
\hline & $\%$ & $P$ value $\left(\chi^{2}\right.$ test $)$ & $\%$ & $P$ value $\left(\chi^{2}\right.$ test $)$ & $\%$ & $P$ value $\left(\chi^{2}\right.$ test $)$ \\
\hline \multicolumn{7}{|l|}{ All students } \\
\hline $\begin{array}{l}\text { Less than weekly (ref.), } n_{\text {students }} 3233 \\
\text { At least weekly, } n_{\text {students }} 1409\end{array}$ & $\begin{array}{l}69.65 \\
30.35\end{array}$ & $<0.0001$ & $\begin{array}{l}63 \cdot 49 \\
36 \cdot 51\end{array}$ & $<0.0001$ & $\begin{array}{l}75 \cdot 69 \\
24 \cdot 31\end{array}$ & $<0.0001$ \\
\hline \multicolumn{7}{|l|}{ Student-perceived access to fast-food outlets } \\
\hline $\begin{array}{l}\text { None (ref.), } n_{\text {students }} 1612 \\
\text { One outlet, } n_{\text {students }} 1159 \\
\text { Two or more outlets, } n_{\text {students }} 1871\end{array}$ & $\begin{array}{l}26 \cdot 12 \\
30.54 \\
33 \cdot 89\end{array}$ & $<0.0001$ & $\begin{array}{l}29.73 \\
35.93 \\
42.51\end{array}$ & $<0.0001$ & $\begin{array}{l}22 \cdot 75 \\
24 \cdot 96 \\
25 \cdot 29\end{array}$ & 0.4232 \\
\hline \multicolumn{7}{|c|}{ Objective measure of access to fast-food outlets } \\
\hline $\begin{array}{l}\text { Zero outlets (ref.), } n_{\text {schools }} 51, n_{\text {students }} 2553 \\
\text { One outlet, } n_{\text {schools }} 12, n_{\text {students }} 848 \\
\text { Two or more outlets, } n_{\text {schools }} 12, n_{\text {students }} 1241 \\
\text { Correlates of fast-food intake }\end{array}$ & $\begin{array}{l}28 \cdot 12 \\
32 \cdot 55 \\
33.44\end{array}$ & 0.0012 & $\begin{array}{l}34.05 \\
37.33 \\
40.95\end{array}$ & 0.0136 & $\begin{array}{l}22 \cdot 40 \\
27 \cdot 54 \\
26 \cdot 11\end{array}$ & 0.0492 \\
\hline \multicolumn{7}{|l|}{ Sex } \\
\hline $\begin{array}{l}\text { Girls (ref.), } n_{\text {students }} 2341 \\
\text { Boys, } n_{\text {students }} 2301\end{array}$ & $\begin{array}{l}24 \cdot 31 \\
36 \cdot 51\end{array}$ & $<0.0001$ & & & & \\
\hline \multicolumn{7}{|l|}{ Grade } \\
\hline $\begin{array}{l}5 \text { th }(\text { ref. }), n_{\text {students }} 1739 \\
7 \text { th, } n_{\text {students }} 1567 \\
\text { 9th, } n_{\text {students }} 1336\end{array}$ & $\begin{array}{l}25.53 \\
28.84 \\
38.40\end{array}$ & $<0.0001$ & $\begin{array}{l}28.90 \\
34.41 \\
48 \cdot 87\end{array}$ & $<0.0001$ & $\begin{array}{l}22 \cdot 2 \\
23 \cdot 43 \\
28 \cdot 08\end{array}$ & 0.0216 \\
\hline \multicolumn{7}{|l|}{ Family social class } \\
\hline $\begin{array}{l}\text { High (ref.), } n_{\text {students }} 1558 \\
\text { Mid, } n_{\text {students }} 1699 \\
\text { Low, } n_{\text {students }} 764 \\
\text { Unclassified, } n_{\text {students }} 621\end{array}$ & $\begin{array}{l}26 \cdot 64 \\
30.90 \\
34.55 \\
33.01\end{array}$ & 0.0003 & $\begin{array}{l}33 \cdot 50 \\
38 \cdot 73 \\
38 \cdot 27 \\
36 \cdot 20\end{array}$ & 0.1509 & $\begin{array}{l}19 \cdot 66 \\
23 \cdot 58 \\
31 \cdot 28 \\
29 \cdot 23\end{array}$ & $<0.0001$ \\
\hline \multicolumn{7}{|l|}{ Language at home } \\
\hline $\begin{array}{l}\text { Non-Danish (ref.), } n_{\text {students }} 282 \\
\text { Danish, } n_{\text {students }} 4360\end{array}$ & $\begin{array}{l}54.96 \\
28.76\end{array}$ & $<0.0001$ & $\begin{array}{l}59 \cdot 20 \\
34 \cdot 65\end{array}$ & $<0.0001$ & $\begin{array}{l}48 \cdot 15 \\
23 \cdot 15\end{array}$ & $<0.0001$ \\
\hline \multicolumn{7}{|l|}{ Travel time to school } \\
\hline $\begin{array}{l}\text { More than } 15 \mathrm{~min} \text { (ref.), } n_{\text {students }} 989 \\
\text { Less than } 15 \mathrm{~min}, n_{\text {students }} 3624\end{array}$ & $\begin{array}{l}27 \cdot 20 \\
31 \cdot 15\end{array}$ & 0.0165 & $\begin{array}{l}34.93 \\
36 \cdot 87\end{array}$ & 0.432 & $\begin{array}{l}19 \cdot 88 \\
25 \cdot 51\end{array}$ & 0.0089 \\
\hline \multicolumn{7}{|l|}{ School leader-reported items } \\
\hline $\begin{array}{l}\text { Allowed (ref.), } n_{\text {schools }} 39, n_{\text {students }} 1547 \\
\text { Not allowed, } n_{\text {schools }} 30, n_{\text {students }} 2821\end{array}$ & $\begin{array}{l}28 \cdot 31 \\
31 \cdot 16\end{array}$ & 0.0499 & $\begin{array}{l}34 \cdot 18 \\
37 \cdot 02\end{array}$ & 0.1893 & $\begin{array}{l}22 \cdot 77 \\
25 \cdot 30\end{array}$ & 0.1833 \\
\hline Canteen in the school & & & & & & \\
\hline $\begin{array}{l}\text { Yes (ref.), } n_{\text {schools }} 8, n_{\text {students }} 847 \\
\text { No, } n_{\text {schools }} 55, n_{\text {students }} 2982\end{array}$ & $\begin{array}{l}35.77 \\
28 \cdot 71\end{array}$ & $<0.0001$ & $\begin{array}{l}40 \cdot 05 \\
35 \cdot 55\end{array}$ & 0.0926 & $\begin{array}{l}31.63 \\
22.04\end{array}$ & $<0.0001$ \\
\hline
\end{tabular}

HBSC, Health Behaviour in School-aged Children; ref., referent category.

Using similar analyses for girls, we show in Table 3 that older girls and those from low social class backgrounds had significantly $41 \%$ and $46 \%$ higher odds, respectively, to report at least weekly fast-food intake compared with their referents. Similarly to boys, girls had 2.37 higher odds to report at least weekly fast-food intake if they spoke Danish at home. Girls with travel time to school of $15 \mathrm{~min}$ or less had $44 \%$ higher odds to consume fast food on an at least weekly basis than girls travelling more than $15 \mathrm{~min}$ to school, and those attending schools with a canteen had $47 \%$ higher odds of reporting at least weekly fast-food consumption than those with no canteens.

\section{Discussion}

Our study examined whether both perceived and objective measures of the fast-food environment were associated with fast-food intake in an adolescent population. Univariate analyses showed that perceived and objective presence of fast-food outlets was associated with a higher frequency of fast-food intake. In the multivariate adjusted analyses, only perceived presence of fast-food outlets was associated with fast-food intake and only among boys. There is risk of overcontrol in the statistical models because some of the covariates may mediate the associations between presence of fast-food outlets and fast-food intake rather than confound them. Since the study is cross-sectional, it is not possible to make a distinct separation of confounder and mediator variables.

Another main finding is that several other sociodemographic and environmental factors were associated with fast-food intake and that the pattern of associations differed between boys and girls. One example is that neighbourhood perception, especially for boys, may be important when considering built environment measures 
Table 3 Multivariate multilevel logistic regression analysis modelling likelihood of at least weekly fast-food consumption; adolescents (n 4642) aged 11-15-years, Danish HBSC study, 2010

\begin{tabular}{|c|c|c|c|c|c|c|}
\hline & \multicolumn{2}{|c|}{ All students } & \multicolumn{2}{|c|}{ Boys } & \multicolumn{2}{|c|}{ Girls } \\
\hline & OR & $95 \% \mathrm{Cl}$ & OR & $95 \% \mathrm{Cl}$ & OR & $95 \% \mathrm{Cl}$ \\
\hline \multicolumn{7}{|l|}{ Student-perceived access to fast-food outlets } \\
\hline None (ref.) & \multicolumn{2}{|c|}{1.00} & \multicolumn{2}{|c|}{1.00} & \multicolumn{2}{|c|}{1.00} \\
\hline One outlet & $1 \cdot 12$ & $0.91,1.39$ & $1 \cdot 13$ & $0.85,1.52$ & 1.05 & $0.77,1.43$ \\
\hline Two or more outlets & 1.17 & $0.95,1.45$ & 1.34 & $1.01,1.78^{*}$ & 1.14 & $0.84,1.56$ \\
\hline \multicolumn{7}{|l|}{ Objective measure of access to fast-food outlets } \\
\hline Zero outlets (ref.) & \multicolumn{2}{|c|}{1.00} & \multicolumn{2}{|c|}{1.00} & \multicolumn{2}{|c|}{1.00} \\
\hline One outlet & 0.99 & $0.73,1.36$ & 0.89 & $0.61,1.30$ & $1 \cdot 13$ & $0.76,1.69$ \\
\hline Two or more outlets & 1.05 & $0.77,1.42$ & 1.03 & $0.71,1.49$ & 1.03 & $0.69,1.55$ \\
\hline \multicolumn{7}{|l|}{ Correlates of fast-food intake } \\
\hline \multicolumn{7}{|l|}{ Sociodemographic } \\
\hline Sex (ref., girls) & \multicolumn{2}{|c|}{1.00} & & & & \\
\hline Boys & 1.78 & $1.53,2 \cdot 08^{\star \star \star}$ & & & \multirow{2}{*}{\multicolumn{2}{|c|}{1.00}} \\
\hline Grade (ref., 5th) & \multicolumn{2}{|c|}{1.00} & \multicolumn{2}{|c|}{1.00} & & \\
\hline 7th & 1.11 & $0.90,1.38$ & $1 \cdot 11$ & $0.85,1.46$ & $1 \cdot 10$ & $0.81,1.48$ \\
\hline 9th & 1.74 & $1 \cdot 40,2 \cdot 18^{\star \star *}$ & $2 \cdot 20$ & $1 \cdot 66,2 \cdot 91^{\star \star *}$ & 1.41 & $1.03,1.92^{*}$ \\
\hline Family social class (ref., high) & \multicolumn{2}{|c|}{$1.14 \quad 1.00^{1.40,2.10}$} & \multicolumn{2}{|c|}{1.00} & \multicolumn{2}{|c|}{1.00} \\
\hline Mid & 1.20 & $0.99,1.44$ & 1.28 & $1.00,1.65^{\star}$ & $1 \cdot 12$ & $0.85,1.49$ \\
\hline Low & 1.20 & $0.95,1.52$ & 0.98 & $0.71,1.36$ & 1.46 & $1.05,2.04^{*}$ \\
\hline Unclassified & 1.21 & $0.94,1.56$ & 0.99 & $0.71,1.39$ & 1.58 & $1 \cdot 09,2 \cdot 29^{*}$ \\
\hline Language (ref., non-Danish) & \multicolumn{2}{|c|}{1.00} & \multicolumn{2}{|c|}{1.00} & \multicolumn{2}{|c|}{1.00} \\
\hline Danish & $2 \cdot 32$ & $1 \cdot 68,3 \cdot 19^{\star \star *}$ & 2.58 & $1.69,3.93^{\star \star \star}$ & $2 \cdot 37$ & $1.46,3 \cdot 84^{\star \star}$ \\
\hline \multicolumn{7}{|l|}{ Behavioural } \\
\hline School travel (ref., $15 \mathrm{~min}$ or more) & \multicolumn{2}{|c|}{1.00} & \multicolumn{2}{|c|}{1.00} & \multicolumn{2}{|c|}{1.00} \\
\hline 15 min or less & $1 \cdot 21$ & $1.00,1.46^{*}$ & 1.02 & $0.79,1.32$ & 1.44 & $1.08,1.93^{\star}$ \\
\hline \multicolumn{7}{|l|}{ School leader-reported items } \\
\hline School leaving policy (ref., not allowed) & \multicolumn{2}{|c|}{1.00} & \multicolumn{2}{|c|}{1.00} & & \\
\hline Allowed for some & 0.98 & $0.76,1.26$ & 0.99 & $0.73,1.34$ & 1.00 & $0.72,1.40$ \\
\hline Canteen in school (ref no) & & & & & & \\
\hline Yes & 1.28 & $0.95,1.73$ & 1.03 & $0.72,1.49$ & 1.47 & $1 \cdot 00,2 \cdot 15^{\star}$ \\
\hline
\end{tabular}

HBSC, Health Behaviour in School-aged Children; ref., referent category.

Association significant at the ${ }^{*} 0.05,{ }^{\star *} 0.01$ and ${ }^{* \star *}<0.001$ levels.

associated with food intake, as we have shown that boys' perception of fast-food outlet location was significantly associated with their fast-food intake, but this was not the case for girls. Second, school lunch location may also be a predictor of at least weekly fast-food intake for girls, emphasizing the need to ensure that school lunch menus contain healthy choices for students. Third, girls who have short commuting times to school may have greater tendency to consume fast food than those with longer commuting times. Lastly, individual factors such as increasing age and low socio-economic family background for girls may contribute to at least weekly intake of fast food.

Our study is unique in concurrently examining both perceived and objective measures of fast-food outlet exposure and fast-food intake among adolescents, and therefore we cannot directly compare it with other studies. However, the results are in general agreement with other adolescent studies examining the relationship between the food environment and food intake, such as that of Longacre et al. ${ }^{(27)}$, who reported a $30 \%$ increase in likelihood to consume fast food in rural areas with high fast-food outlet exposure, and Davis and Carpenter ${ }^{(18)}$, who found decreased fruit and vegetable consumption but increased soft drink intake with fast-food outlet exposure.
Our findings illustrate potential sex differences in neighbourhood perception of the built environment. We have demonstrated that boys' perception of fast-food outlet location was significantly associated with fast-food intake. Potential explanations for this finding may be due to sex differences in spatial navigation ${ }^{(58-60)}$, as well as differences in perceived fast-food availability ${ }^{(61)}$. Another explanation may be related to a greater proportion of boys eating fast food than girls, as frequency of consumption may be associated to a heightened awareness of surroundings ${ }^{(36)}$. In order to further examine such differences, future studies may consider more in-depth analyses of how boys and girls use and interpret their local surroundings.

Study findings also show that the presence of a school canteen is especially important in predicting at least weekly fast-food intake in girls. We were surprised by this result, as one would expect that the presence of canteens may encourage healthier food habits ${ }^{(49,52)}$; however, many schools worldwide still struggle to achieve healthier food and nutrient standards despite policy improvements ${ }^{(62,63)}$. It would be beneficial in the future to examine school canteen offerings to assess nutritional quality and acceptability, or whether girls are bringing in food purchased elsewhere. While school leaving policies were not 
significantly associated with fast-food intake in our population as found by Woodruff and collegues ${ }^{(64)}$, there is a need to teach students about healthier lunch options if leaving the school during the lunch period.

The study illustrates that girls with shorter commuting times to school had a greater tendency to consume fast food than those with longer commuting times. Our findings are in general agreement with studies examining school travel time and snack and fast-food behaviour among adolescents. Students who travel to and from school within a short time frame are more likely to either walk or cycle ${ }^{(65)}$, which increases exposure to foodbuying opportunities within the local area ${ }^{(56)}$. As shown by Hearst et al. ${ }^{(36)}$, increased exposure time within the local area may translate to an increase in purchasing behaviours of snack and fast foods.

Lastly, individual factors such as increasing age for all students and low socio-economic family background for girls may contribute to at least weekly intake of fast food. Our findings are in general agreement with previous research indicating greater fast-food consumption as adolescents increase in age ${ }^{(7,44)}$. However, age may also serve as an indicator for mobility within local surroundings $^{(66)}$, as well as age-acquired spatial knowledge ${ }^{(67)}$; age should be an important consideration in future research. Our research also shows girls from low-income backgrounds reported more frequent intake of fast food than girls from high-income ones. The association with family social background was found to be reversed in a Chinese population of adolescents ${ }^{(68)}$ and of no significance in Dutch adults ${ }^{(69)}$. The lack of consistent findings between family social background and fast-food consumption may indicate that the complexity in this relationship may be dependent upon other factors, such as lack of time to prepare healthy meals ${ }^{(69)}$ or lack of work-life balance expressed by working parents ${ }^{(70)}$, which may also increase propensity for fast-food consumption.

Study strengths include the large and nationally representative study population and the incorporation of both perceived and objective measures of the fast-food environment, which further contributes to our understanding of how perception of local surroundings may influence dietary behaviour. The study also benefits from the use of validated objective measures, the inclusion of three age groups, simultaneous control of potential confounding variables, a high student response rate and a nationwide random sample of schools.

Our study, however, is limited by possible misclassification bias of the objective measure of the fast-food outlet environment, as we did not include all other food outlets that could sell fast food, such as cafés or convenience stores, which could potentially under-report the number of food-purchasing opportunities for adolescents. Street audits showed good overall concurrence among fast-food outlets, yet previous work indicates discrepencies among other types of food outlets such as convenience stores or cafés ${ }^{(32)}$. Positive response bias ${ }^{(71)}$ could also be a limitation of the present study, as it is often used as a rationale for using different data sources for measures of correlates and outcomes such as the fast-food environment and fast-food intake. Previous analyses showed adolescent fast-food intake was not a predictor of mismatch between objective and perceived measures of the environment. Thus, students' perceptions of the fast-food environment do not seem to be subject to positive response bias.

Other drawbacks of the study could be reflected in the distance measure used to characterize the local fast-food outlet exposure, which may not realistically reflect actual usage and may be sensitive to other travel and distance measures. Others found significant associations between food purchasing and $10 \mathrm{~min}$ of travel ${ }^{(36)}$. While future studies should explore various ranges of travel times, our illustration within a short local radius was to demonstrate how readily students may be exposed to fast-food outlets. We also realize that although the use of questionnaire methods to collect perceived information of the neighbourhood built environment among adolescents is a widely used approach ${ }^{(36,72-74)}$, there are also other tools such as community map sketches ${ }^{(75)}$, photo-voice ${ }^{(76)}$ and concept mapping ${ }^{(77)}$ that may help elucidate detailed information about food environments relevant for youth. As there was also a proportion of students who were unable to locate a fast-food outlet in the local area, there may also be an indication that some students may not be fully cognizant of the term, fast food. It may be necessary to explore how adolescents in Denmark conceptualize the meaning of fast food, as others have found adults differentiate between fast food and restaurant food ${ }^{(78)}$, while the image of fast-food outlets is in flux, as many offer healthier menu items ${ }^{(79)}$. We acknowledge that other correlates such as peer networks ${ }^{(80)}$, accessibility, affordability and taste preference ${ }^{(81)}$ as well as safety ${ }^{(75)}$ may also influence perception of fast-food outlet location and consumption. Lastly, we realize the risk of overcontrol in the multivariate analyses, yet examination of univariate and multivariate analyses suggests that overcontrol may not be a threat in our study.

To our knowledge, the present study is the first to examine both perceived and objective measures of the fast-food environment and fast-food intake in an adolescent population, which demonstrates that perceived location of food outlets may have an impact on fast-food intake behaviour in boys. Findings from the study contribute to a growing body of knowledge examining the impact of local surroundings and dietary behaviours in adolescents. Other aspects, such as travel time to school, may be a guiding factor, as increased exposure within a specific area may increase tendency towards consumption and purchasing behaviours. Inspiring schools to make either campuses or school lunch offerings more attractive, encourage healthier purchase of foods or better support school nutrition policies may reduce the need to consume 
food elsewhere. Further exploration should examine not only sex differences in fast-food intake behaviour, but also how boys and girls interpret their local surroundings. Greater attention should also be directed towards a better understanding of how resources within the school and local areas contribute to dietary behaviour. Implications of the study findings could impact public health planning that targets food environments specifically for adolescents, recognizing where they purchase and eat food, both within school and local surroundings.

\section{Acknowledgements}

Acknowledgements: Special thanks go to Jindong Ding Petersen, Nishan Lamichhane and Laurence Blanchard, who worked on the validation of the objective data. The authors acknowledge Professor Pernille Due and Associated Professor Mette Rasmussen for making the 2010 HBSC data available for analysis. Financial support: This work was funded in part by Nordea Fonden. Nordea Fonden had no role in the design, analysis or writing of this article. Conflict of interest: None. Authorship: C.S. was responsible for conception of the study, study design, collection and setup. C.S. and R.K. were involved with study analysis. C.S. and R.K. drafted the initial manuscript. J.S., T.P.P., B.E.H. and S.E.J. provided feedback and guidance regarding drafts of the manuscript. All authors were involved with critical revisions of the paper and provided approval for publication. Ethics of human subject participation: Ethical approval was not required for this study. However, the study was conducted according to the guidelines laid down by the Helsinki Declaration and all procedures involving human subjects were approved by local school, student and parent boards. Verbal informed consent was obtained for all subjects, and this was witnessed and formally recorded. This study is registered with the Danish Data Protection Agency.

\section{References}

1. Matthiessen J, Fagt S, Biltoft-Jensen A et al. (2003) Size makes a difference. Public Health Nutr 6, 65-72.

2. Lake AA, Burgoine T, Greenhalgh F et al. (2010) The foodscape: classification and field validation of secondary data sources. Health Place 16, 666-673.

3. Duffey KJ, Gordon-Larsen P, Steffen LM et al. (2009) Regular consumption from fast food establishments relative to other restaurants is differentially associated with metabolic outcomes in young adults. J Nutr 139, 2113-2118.

4. Piernas C \& Popkin BM (2011) Food portion patterns and trends among US children and the relationship to total eating occasion size, 1977-2006. J Nutr 141, 1159-1164.

5. Fraser LK, Edwards KL, Cade JE et al. (2011) Fast food, other food choices and body mass index in teenagers in the United Kingdom (ALSPAC): a structural equation modelling approach. Int J Obes (Lond) 35, 1325-1330.
6. Rosenheck R (2008) Fast food consumption and increased caloric intake: a systematic review of a trajectory towards weight gain and obesity risk. Obes Rev 9, 535-547.

7. Bauer KW, Larson NI, Nelson MC et al. (2009) Fast food intake among adolescents: secular and longitudinal trends from 1999 to 2004. Prev Med 48, 284-287.

8. Lachat C, Khanh le NB, Huynh TT et al. (2012) Factors associated with eating out of home in Vietnamese adolescents. Appetite 57, 649-655.

9. Poti JM \& Popkin BM (2011) Trends in energy intake among US children by eating location and food source, 1977-2006. J Am Diet Assoc 111, 1156-1164.

10. Paeratakul S, Ferdinand DP, Champagne CM et al. (2003) Fast-food consumption among US adults and children: dietary and nutrient intake profile. J Am Diet Assoc 103, 1332-1338.

11. Powell LM, Chaloupka FJ \& Bao Y (2007) The availability of fast-food and full-service restaurants in the United States: associations with neighborhood characteristics. Am J Prev Med 33, 4 Suppl., S240-S245.

12. Feeley A, Musenge E, Pettifor JM et al. (2012) Changes in dietary habits and eating practices in adolescents living in urban South Africa: the birth to twenty cohort. Nutrition $\mathbf{2 8}$, e1-e6.

13. Guldan GS (2013) Asian children's obesogenic diets - time to change this part of the energy balance equation? Res Sports Med 18, 5-15.

14. Austin SB, Melly SJ, Sanchez BN et al. (2005) Clustering of fast-food restaurants around schools: a novel application of spatial statistics to the study of food environments. Am J Public Health 95, 1575-1581.

15. Simon PA, Kwan D, Angelescu A et al. (2008) Proximity of fast food restaurants to schools: do neighborhood income and type of school matter? Prev Med 47, 284-288.

16. Sturm R (2008) Disparities in the food environment surrounding US middle and high schools. Public Health 122, 681-690.

17. Zenk SN \& Powell LM (2008) US secondary schools and food outlets. Health Place 14, 336-346.

18. Davis B \& Carpenter C (2009) Proximity of fast-food restaurants to schools and adolescent obesity. Am J Public Health 99, 505-510.

19. Kipke MD, Iverson E, Moore D et al. (2007) Food and park environments: neighborhood-level risks for childhood obesity in east Los Angeles. $J$ Adolesc Health 40, 325-333.

20. Kestens Y \& Daniel M (2010) Social inequalities in food exposure around schools in an urban area. Am J Prev Med 39, 33-40.

21. Kwate NO \& Loh JM (2010) Separate and unequal: the influence of neighborhood and school characteristics on spatial proximity between fast food and schools. Prev Med 51, 153-156.

22. Neckerman KM, Bader MD, Richards CA et al. (2010) Disparities in the food environments of New York City public schools. Am J Prev Med 39, 195-202.

23. Day PL \& Pearce J (2011) Obesity-promoting food environments and the spatial clustering of food outlets around schools. Am J Prev Med 40, 113-121.

24. Smith D, Cummins S, Clark C et al. (2013) Does the local food environment around schools affect diet? Longitudinal associations in adolescents attending secondary schools in East London. BMC Public Health 13, 70.

25. Hackett A, Boddy L, Boothby J et al. (2008) Mapping dietary habits may provide clues about the factors that determine food choice. J Hum Nutr Diet 21, 428-437.

26. He M, Tucker P, Irwin JD et al. (2012) Obesogenic neighbourhoods: the impact of neighbourhood restaurants and convenience stores on adolescents' food consumption behaviours. Public Health Nutr 15, 2331-2339.

27. Longacre MR, Drake KM, MacKenzie TA et al. (2012) Fast-food environments and family fast-food intake in nonmetropolitan areas. Am J Prev Med 42, 579-587. 
28. van der Horst K, Timperio A, Crawford D et al. (2008) The school food environment associations with adolescent soft drink and snack consumption. Am J Prev Med 35, 217-223.

29. Laska MN, Hearst MO, Forsyth A et al. (2010) Neighbourhood food environments: are they associated with adolescent dietary intake, food purchases and weight status? Public Health Nutr 13, 1757-1763.

30. Caspi CE, Kawachi I, Subramanian SV et al. (2012) The relationship between diet and perceived and objective access to supermarkets among low-income housing residents. Soc Sci Med 75, 1254-1262.

31. Powell LM, Han E, Zenk SN et al. (2011) Field validation of secondary commercial data sources on the retail food outlet environment in the US. Health Place 17, 1122-1131.

32. Svastisalee CM, Holstein BE \& Due P (2012) Validation of presence of supermarkets and fast-food outlets in Copenhagen: case study comparison of multiple sources of secondary data. Public Health Nutr 15, 1228-1231.

33. Moore LV, Diez Roux AV \& Brines S (2008) Comparing perception-based and geographic information system (GIS)based characterizations of the local food environment. J Urban Health 85, 206-216.

34. Williams LK, Thornton L, Ball K et al. (2012) Is the objective food environment associated with perceptions of the food environment? Public Health Nutr 15, 291-298.

35. Sharkey JR, Johnson CM \& Dean WR (2010) Food access and perceptions of the community and household food environment as correlates of fruit and vegetable intake among rural seniors. BMC Geriatr 10, 32.

36. Hearst MO, Pasch KE \& Laska MN (2012) Urban $v$. suburban perceptions of the neighbourhood food environment as correlates of adolescent food purchasing. Public Health Nutr 15, 299-306.

37. Currie C, Nic Gabhainn S \& Godeau E (2009) The Health Behaviour in School-aged Children: WHO Collaborative Cross-National (HBSC) study: origins, concept, history and development 1982-2008. Int J Public Health 54, Suppl. 2, 131-139.

38. Roberts C, Freeman J, Samdal O et al. (2009) The Health Behaviour in School-aged Children (HBSC) study: methodological developments and current tensions. Int J Public Health 54, Suppl. 2, 140-150.

39. Svastisalee CM, Nordahl H, Glümer C et al. (2011) Supermarket and fast-food outlet exposure in Copenhagen: associations with socio-economic and demographic characteristics. Public Health Nutr 14, 1618-1626.

40. Paquet C, Daniel M, Kestens Y et al. (2008) Field validation of listings of food stores and commercial physical activity establishments from secondary data. Int J Behav Nutr Phys Act 5, 58

41. Skidmore P, Welch A, van Sluijs E et al. (2010) Impact of neighbourhood food environment on food consumption in children aged 9-10 years in the UK SPEEDY (Sport, Physical Activity and Eating behaviour: Environmental Determinants in Young people) study. Public Health Nutr 13, 1022-1030.

42. Affuso O, Stevens J, Catellier D et al. (2011) Validity of selfreported leisure-time sedentary behavior in adolescents. J Negat Results Biomed 10, 2.

43. Department of Transport, Local Government and the Regions (2009) National Travel Survey: 2009. London: Office for National Statistics.

44. Denney-Wilson E, Crawford D, Dobbins T et al. (2009) Influences on consumption of soft drinks and fast foods in adolescents. Asia Pac J Clin Nutr 18, 447-452.

45. Fletcher A, Bonell C \& Sorhaindo A (2011) You are what your friends eat: systematic review of social network analyses of young people's eating behaviours and bodyweight. J Epidemiol Community Health 65, 548-555.
46. Lachat C, Nago E, Verstraeten R et al. (2012) Eating out of home and its association with dietary intake: a systematic review of the evidence. Obes Rev 13, 329-346.

47. Svastisalee CM, Holstein BE \& Due P (2012) Fruit and vegetable intake in adolescents: association with socioeconomic status and exposure to supermarkets and fast food outlets. J Nutr Metab 2012, 185484.

48. Gosliner W, Madsen KA, Woodward-Lopez G et al. (2011) Would students prefer to eat healthier foods at school? J Sch Health 81, 146-151.

49. Raulio S, Roos E \& Prattala R (2010) School and workplace meals promote healthy food habits. Public Health Nutr $\mathbf{1 3}$, 987-992.

50. Townsend N, Murphy S \& Moore L (2011) The more schools do to promote healthy eating, the healthier the dietary choices by students. J Epidemiol Community Health $\mathbf{6 5}$, 889-895.

51. de Moraes AC, Adami F \& Falcao MC (2012) Understanding the correlates of adolescents' dietary intake patterns. A multivariate analysis. Appetite 58, 1057-1062.

52. Dubuisson C, Lioret S, Dufour A et al. (2012) Associations between usual school lunch attendance and eating habits and sedentary behaviour in French children and adolescents. Eur J Clin Nutr 66, 1335-1341.

53. Samuelson G (2000) Dietary habits and nutritional status in adolescents over Europe. An overview of current studies in the Nordic countries. Eur J Clin Nutr 54, Suppl. 1, S21-S28.

54. Lyng N, Fagt S, Davidsen M et al. (2013) Reporting accuracy of packed lunch consumption among Danish 11-year-olds differ by gender. Food Nutr Res 2013, 57.

55. Sabinsky MS, Toft U, Andersen KK et al. (2012) Development and validation of a Meal Index of dietary Quality (Meal IQ) to assess the dietary quality of school lunches. Public Health Nutr 15, 2091-2099.

56. Lehnung M, Leplow B, Ekroll V et al. (2003) The role of locomotion in the acquisition and transfer of spatial knowledge in children. Scand J Psychol 44, 79-86.

57. Neumark-Sztainer D, French SA, Hannan PJ et al. (2005) School lunch and snacking patterns among high school students: associations with school food environment and policies. Int J Behav Nutr Phys Act 2, 14.

58. Wolbers $\mathrm{T} \&$ \& Hegarty M (2010) What determines our navigational abilities? Trends Cogn Sci 14, 138-146.

59. Zelanti PS \& Droit-Volet S (2011) Cognitive abilities explaining age-related changes in time perception of short and long durations. I Exp Child Psychol 109, 143-157.

60. Leon I, Cimadevilla JM \& Tascon L (2014) Developmental gender differences in children in a virtual spatial memory task. Neuropsychology 28, 485-495.

61. Lucan SC, Barg FK \& Long JA (2010) Promoters and barriers to fruit, vegetable, and fast-food consumption among urban, low-income African Americans - a qualitative approach. Am J Public Health 100, 631-635.

62. Pearce J, Wood L \& Nelson M (2013) Lunchtime food and nutrient intakes of secondary-school pupils; a comparison of school lunches and packed lunches following the introduction of mandatory food-based standards for school lunch. Public Health Nutr 16, 1126-1131.

63. de Silva-Sanigorski A, Breheny T, Jones L et al. (2011) Government food service policies and guidelines do not create healthy school canteens. Aust N Z J Public Health 35 , $117-121$.

64. Woodruff SJ, Hanning RM \& McGoldrick K (2010) The influence of physical and social contexts of eating on lunchtime food intake among southern Ontario, Canada, middle school students. J Sch Health 80, 421-428.

65. De Meester F, Van Dyck D, De Bourdeaudhuij I et al. (2013) Does the perception of neighborhood built environmental attributes influence active transport in adolescents? Int $J$ Behav Nutr Phys Act 10, 38. 
66. Malone K (2002) Street life: youth, culture and competing uses of public space. Environ Urban 14, 157-168.

67. Jansen-Osmann P \& Fuchs P (2006) Wayfinding behavior and spatial knowledge of adults and children in a virtual environment: the role of landmarks. Exp Psychol 53, 171-181.

68. Shi Z, Lien N, Kumar BN et al. (2005) Socio-demographic differences in food habits and preferences of school adolescents in Jiangsu Province, China. Eur J Clin Nutr 59, $1439-1448$

69. Van der Horst K, Brunner TA \& Siegrist M (2011) Fast food and take-away food consumption are associated with different lifestyle characteristics. J Hum Nutr Diet 24, 596-602.

70. Bauer KW, Hearst MO, Escoto K et al. (2012) Parental employment and work-family stress: associations with family food environments. Soc Sci Med 75, 496-504.

71. Diez Roux AV (2007) Neighborhoods and health: where are we and were do we go from here? Rev Epidemiol Sante Publique 55, 13-21.

72. Rosenberg D, Ding D, Sallis JF et al. (2009) Neighborhood Environment Walkability Scale for Youth (NEWS-Y): reliability and relationship with physical activity. Prev Med $\mathbf{4 9}$, 213-218.

73. Hager ER, Witherspoon DO, Gormley C et al. (2013) The perceived and built environment surrounding urban schools and physical activity among adolescent girls. Ann Behav Med 45, Suppl. 1, S68-S75.

74. Carroll-Scott A, Gilstad-Hayden K, Rosenthal L et al. (2013) Disentangling neighborhood contextual associations with child body mass index, diet, and physical activity: the role of built, socioeconomic, and social environments. Soc Sci Med 95, 106-114.

75. Topmiller M, Jacquez F, Vissman AT et al. (2015) Partnering with youth to map their neighborhood environments: a multilayered GIS approach. Fam Community Health 38, $66-76$.

76. Morales-Campos DY, Parra-Medina D \& Esparza LA (2015) Picture this!: using participatory photo mapping with Hispanic girls. Fam Community Health 38, 44-54.

77. Minh A, Patel S, Bruce-Barrett C et al. (2015) Letting youths choose for themselves: concept mapping as a participatory approach for program and service planning. Fam Community Health 38, 33-43.

78. Duffey KJ, Gordon-Larsen P, Jacobs DR Jr et al. (2007) Differential associations of fast food and restaurant food consumption with 3-y change in body mass index: the Coronary Artery Risk Development in Young Adults Study. Am J Clin Nutr 85, 201-208.

79. Wellard L, Glasson C \& Chapman K (2012) Sales of healthy choices at fast food restaurants in Australia. Health Promot J Aust 23, 37-41.

80. Wouters EJ, Larsen JK, Kremers SP et al. (2010) Peer influence on snacking behavior in adolescence. Appetite $\mathbf{5 5}$, 11-17.

81. Shepherd J, Harden A, Rees R et al. (2006) Young people and healthy eating: a systematic review of research on barriers and facilitators. Health Educ Res 21, 239-257. 